\title{
DETERMINAN PERSEPSI MENGENAI ETIKA ATAS PENGGELAPAN PAJAK (TAX EVASION)
}

\author{
Mujiyati $^{1}$ \\ * Prodi Akuntansi Fakultas Ekonomi dan Bisnis, Universitas Muhammadiyah Surakarta \\ *Mujiyati@ums.ac.id ${ }^{1}$ \\ Fitria Riski Rohmawati ${ }^{2}$ \\ * Prodi Akuntansi Fakultas Ekonomi dan Bisnis, Universitas Muhammadiyah Surakarta \\ *b2001303113@student.ums.ac.id ${ }^{2}$ \\ Wahyu Hening Ririn $\mathrm{P}^{2}$ \\ * Prodi Akuntansi Fakultas Ekonomi dan Bisnis, Universitas Muhammadiyah Surakarta \\ *b200130327@student.ums.ac.id ${ }^{2}$
}

\begin{abstract}
This study aims to examine the factors that influence the perception of ethics on tax evasion in the lecturers and students of Muhammadiyah University of Surakarta. The variables used in this study are the dependent variables, namely the perception of ethics on tax evasion, while the independent variables used Are justice, taxation systems, discrimination, the quality of tax services, and the possibility of fraud detection.

The sample in this research is lecturer and student at university muhammadiyah surakarta. Sample collection method used in this research is convenience sampling taken 84 sample lecturer and 100 student sample. The data used in this study is the primary data by using questionnaires. Data analysis in this research is assisted by using SPSS program. Data analysis technique used is multiple linear regression.

The result of the research shows that significant at level 0,05 variable of system of taxation to lecturer, discrimination on lecturer and student, and quality of tax service to lecturer and student have significant influence to perception about ethics on tax evasion. While the variable of justice in lecturer and student, system of taxation to student, and possibility of detection of fraud on lecturer and student have no effect and insignificant to perception about ethics of tax evasion.
\end{abstract}

Keywords: ethical perception, tax evasion, justice taxation system, discrimination, quality of tax service, possible fraud detection.

\section{Pendahuluan}

Sumber penerimaan keuangan di Indonesia salah satu pokok utamanya bersumber dari pajak. Peranan pajak sangat dominan terhadap pendapatan Negara. Besar-kecilnya pajak akan menetukan kapasitas anggaran negara, baik untuk pembiayaan anggaran rutin maupun pembangunan. Menurut Undang-Undang Nomor 16 Tahun 2009 Pasal 1, ayat 1 menyatakan bahwa "pajak adalah kontribusi wajib pajak kepada Negara yang terhutang oleh orang pribadi atau badan yang bersifat memaksa berdasarkan Undang-Undang, dengan tidak mendapatkan imbalan secara langsung dan digunakan untuk keperluan Negara bagi sebesar-besarnya kemakmuran rakyat".

Akan tetapi tidak banyak rakyat yang dapat merasakan apa yang telah mereka keluarkan. Selain itu, dikatakan penerimaan pajak meningkat setiap tahunnya, tetapi bentuk dari pengeluaran negara tersebut masih belum jelas dirasakan oleh masyarakat. Apabila hal tersebut terus-menerus berlanjut, dikhawatirkan akan mengakibatkan keengganan rakyat untuk membayar pajak bahkan akan cenderung menggelapkan pajak (Pulungan, 2015). Terdapat perbedaan pandangan mengenai pajak antara 
pemerintah dengan wajib pajak. Pemerintah sangat memerlukan penerimaan pajak untuk pembiayaan penyelenggaraan negara dan pembangunan. Pajak merupakan sumber sumber penerimaan terbesar bagi negara, sehingga pemerintah mengharapkan wajib pajak untuk patuh membayar pajak dengan mengeluarkan peraturan-peraturan perpajakan. Di pihak lain, wajib pajak memandang bahwa pembayaran pajak merubahan suatu beban yang nantinya dapat mengurangi pendapatannya. Wajib pajak berusaha akan meminimalkan membayar pajak dengan tujuan untuk memaksimalkan jumlah laba yang diterima.

Ada beberapa cara yang digunakan wajib pajak untuk meminimalkan beban pajaknya, yaitu: Tax planning (perencanaan pajak), Tax avoidance (penghindaran pajak) dan Tax evasion (penggelapan pajak). Tax planning adalah upaya wajib pajak untuk meminimalkan beban pajak melalui skema yang memang telah jelas diatur dalam peraturan perundangundangan perpajakan. Perencanaan pajak dapat dilakukan dengan berbagai cara yaitu dengan yang masih memenuhi ketentuan perpajakan (lawful) maupun yang melanggar peraturan perpajakan (unlawful). Tax avoidance adalah suatu usaha meminimalkan beban pajak dengan memanfaatkan celah-celah ketentuan perpajakan suatu negara yang ada. Tax avoidance bisa jadi tidak melanggar hukum, namun sebenarnya upaya ini bertentangan dengan tujuan dibuatnya peraturan perundang-undangan. Tax evasion adalah suatu usaha untuk menghindari pajak terutang dengan cara melanggar undang-undang perpajakan, misalnya wajib pajak tidak melaporkan pendapatan yang sebenarnya. Sulitnya penerapan tax planning dan tax avoidance membuat seseorang wajib pajak cenderung untuk melakukan tax evasion (Silaen, 2015).

Perilaku penggelapan pajak merupakan perilaku ilegal karena melanggar undang-undang atau peraturan yang berlaku. Namun dalam penerapannya perilaku tersebut akan menjadi etis atau wajar untuk dilakukan. Mengingat banyaknya tindakan yang tidak seharusnya dilakukan oleh para pemimpin yaitu seperti menyalahgunakan dana pajak untuk kepentingan pribadi ataupun kelompok, tidak tersistematisnya sistem perpajakan, dan adanya peraturan perpajakan yang dianggap hanya menguntungkan satu pihak dan merugikan pihak lainnya. Dengan adanya hal tersebut membuat wajib pajak tidak segan untuk melakukan penggelapan pajak karena mereka berasumsi beban pajak yang akan dikeluarkan tidak akan dikelola dengan baik dan sehingga timbul anggapan perilaku tersebut etis dan wajar dilakukan (Indriyani, Nurlaela dan Wahyuningsih, 2016).

Penelitian ini bertujuan membandingkan apakah ada perbedaan antara persepsi dosen dan mahasiswa mengenai etika atas penggelapan pajak (tax evasion). Faktor yang akan diuji dalam penelitian ini adalah Keadilan, Sistem Perpajakan, Diskriminasi, Kualitas Pelayanan Pajak, dan Kemungkinan Terdeteksinya Kecurangan pada dosen dan mahasiswa Universitas Muhammadiyah Surakarta.

\section{Kajian Pustaka dan Pengembangan Hipotesis} Teori Atribusi (Atribution Theory)

Pada dasarnya teori atribusi menurut Robbins (1996) dalam Mukharoroh (2014) menyatakan bahwa bila seorang individu mengamati prilaku seseorang, maka mereka akan mencoba untuk menentukan apakah perilaku tersebut ditimbulkan secara internal atau eksternal. Perilaku yang disebabkan secara internal adalah perilaku yang dipengaruhi dari dalam diri individu, sedangkan perilaku yang disebabkan secara eksternal adalah perilaku yang dipengaruhi dari luar individu, artinya individu akan berperilaku bukan karena keinginannya sendiri, melainkan karena desakan atau keadaan yang tidak bisa terkontrol.

\section{Perpajakan}

Menurut Prof. Dr. Rochmat Soemitro,SH dalam Mardiasmo (2011:1) Pajak adalah iuran rakyat kepada kas negara berdasarkan undang-undang (yang dapat dipaksakan) dengan tiada mendapat jasa timbal (kontraprestasi) yang langsung dapat ditunjukkan dan yang digunakan untuk membayar pengeluaran umum.

\section{Penggelapan Pajak}

Menurut Mardiasmo (2011) penggelapan pajak adalah usaha yang dilakukan oleh wajib pajak untuk meringankan beban pajak dengan cara yang tidak legal atau melanggar undang-undang. Dalam hal ini, wajib pajak mengabaikan ketentuan formal perpajakan yang 
menjadi kewajibannya, memasulkan dokumen, atau mengisi data dengan tidak lengkap dan tidak benar.

\section{Etika}

Etika berasal dari kata ethos sebuah kata dari Yunani, yang diartikan identik dengan moral atau moralitas dan dijadikan sebagai pedoman atau ukuran bagi tindakan manusia dengan penilaian baik atau buruk dan benar atau salah (Untung, 2012 dalam Abrahams dan Kristanto, 2016).

\section{Keadilan}

Menurut Kamus Besar Bahasa Indonesia, keadilan memiliki kata dasar adil yang berarti sama berat, tidak berat sebelah, tidak memihak, berpegang pada kebenaran, sepatutnya, dan tidak sewenangwenang. Siahaan (2010) dalam Ningsih dan Pusposari (2014)membagi tiga aspek keadilan yang perlu diperhatikan dalam penerapan pajak, antara lain keadilan dalam penyusunan dan pelaksanaan undangundang pajak, serta keadilan dalam penggunaan uang pajak.

\section{Sistem Perpajakan}

Kamus Besar Bahasa Indonesia menjelaskan sistem merupakan perangkat unsur yang secara teratur saling berkaitan sehingga membentuk suatu susunan tertentu. Sistem perpajakan yang baik menurut Suminarsasi (2012) dalam Abrahams dan Kristanto (2016) adalah pengelolaan uang pajak yang dapat dipertanggungjawabkan, petugas pajak yang kompeten dan tidak korup serta prosedur perpajakan yang tidak berbelit-belit.

\section{Diskriminasi}

Menurut Danandjaja (2003) dalam Abrahams dan Kristanto (2016), diskriminasi adalah perlakuan yang tidak seimbang terhadap perorangan, atau kelompok, berdasarkan sesuatu, biasanya bersifat kategorikal, atau atribut-atribut khas, seperti berdasarkan ras, kesukubangsaan, agama, atau keanggotaan kelas-kelas sosial. Diskriminasi dalam bidang perpajakan menunjuk pada kondisi dimana pemerintah memberikan pelayanan perpajakan dengan tidak seimbang terhadap masyarakat maupun wajib pajak.

\section{Kualitas Pelayanan Pajak}

Menurut Murni, et al (2013) dalam Tobing (2015), pelayanan petugas pajak terhadap wajib pajak cukup menentukan dalam pengambilan keputusan wajib pajak membayar pajak. Hal tersebut disebabkan karena wajib pajak telah memberikan kontribusi yang besar kepada negara dengan membayar pajak. Ketika wajib pajak merasa pelayanan yang diberikan kepadanya tidak sesuai dengan apa yang diharapkan, maka wajib pajak cenderung akan melakukan kecurangan yaitu penggelapan pajak, dan sebaliknya jika pelayanan yang diberikan oleh petugas pajak sudah baik dan dapat memenuhi harapan wajib pajak maka wajib pajak akan cenderung patuh membayar pajak.

\section{Kemungkinan Terdeteksinya Kecurangan}

Kecurangan adalah tindakan melawan hukum, penipuan berencana, dan bermakna ketidakjujuran (Yetmi, Darmayanti, dan Muslim, 2014). Kemungkinan terdeteksinya kecurangan adalah seberapa besar kemungkinan terdeteksi kecurangan jika dilakukan pemeriksaan (Rahman, 2013). Pasal 1 angka 25 Undang-undang Nomor 16 tahun 2009 tentang Ketentuan Umum dan Tata Cara Perpajakan, pemeriksaan adalah serangkaian kegiatan menghimpun dan mengolah data, keterangan, dan/atau bukti yang dilaksanakan secara objektif dan profesional berdasarkan suatu standar pemeriksaan untuk menguji kepatuhan pemenuhan kewajiban perpajakan dan/atau untuk tujuan lain dalam rangka melaksanakan ketentuan peraturan perundang-undangan perpajakan.

\section{Pengaruh Keadilan Terhadap Persepsi Mengenai Etika Atas Penggelapan Pajak.}

Dengan tingkat keadilan yang tinggi akan meningkatkan kepercayaan masyarakat terhadap pemerintah, sehingga akan timbul rasa percaya dan aman ketika masyarakat membayarkan uang pajak. Sehingga masyarakat khususnya dosen akan beranggapan bahwa penggelapan pajak yang melanggar aturan dan merugikan masyarakat secara luas merupakan tindakan yang tidak etis untuk dilakukan.

Berdasarkan penelitian sebelumnya Ningsih dan Pusposari (2014) menunjukkan bahwa keadilan berpengaruh terhadap persepsi mengenai etika atas penggelapan pajak, yaitu semakin tinggi tingkat keadilan di pemerintahan suatu negara, maka 
masyarakatnya akan memiliki persepsi bahwa penggelapan pajak merupakan tindakan yang tidak etis. Dengan demikian hipotesis yang diajukan:

$\mathrm{H}_{1}$ : Keadilan berpengaruh terhadap persepsi mengenai etika atas penggelapan pajak.

\section{Pengaruh Sistem Perpajakan Terhadap Persepsi Mengenai Etika Atas Penggelapan Pajak.}

Kemudahan sistem perpajakan yang ada akan mendorong kemauan masyarakat untuk membayar pajak (Suminarsasi dan Supriyadi, 2011). Dengan sistem perpajakan yang baik akan memberikan kemudahan dan mendorong kemauan masyarakat dalam melakukan kewajiban perpajakan, serta mempercayai pemerintah dalam mengelola uang pajak sesuai aturannya. Sehingga, masyarakat khususnya dosen akan beranggapan bahwa penggelapan pajak yang melanggar aturan dan merugikan masyarakat secara luas merupakan tindakan yang tidak etis untuk dilakukan

Berdasarkan penelitian sebelumnya Suminarsasi dan Supriyadi (2011), dan Ningsih dan Pusposari (2014) menunjukkan bahwa semakin baik sistem perpajakannya maka perilaku penggelapan pajak dipandang sebagai perilaku yang tidak etis, sebaliknya semakin tidak baik sistem perpajakannya maka perilaku penggelapan pajak dipandang sebagai perilaku yang cenderung etis. Dengan demikian hipotesis yang diajukan:

$\mathrm{H}_{2}$ : Sistem perpajakan berpengaruh terhadap persepsi wajib pajak mengenai etika penggelapan pajak.

\section{Pengaruh Diskriminasi Terhadap Persepsi Mengenai Etika Atas Penggelapan Pajak.}

Semakin banyak peraturan perpajakan yang dianggap sebagai bentuk diskriminasi yang merugikan, maka masyarakat akan cenderung untuk tidak patuh terhadap aturan. Ketidakpatuhan ini dapat berakibat pada masyarakat yang enggan membayar pajak (Ariyanti, 2013) dalam (Ningsih dan Pusposari, 2014). Sehingga, masyarakat khususnya dosen akan beranggapan penggelapan pajak merupakan tindakan yang etis untuk dilakukan.
Berdasarkan penelitian sebelumnya Suminarsasi dan Supriyadi (2011), dan Ningsih dan Pusposari (2014) menunjukkan bahwa Semakin banyak bentuk diskriminasi dalam suatu negara, maka masyarakatnya memiliki persepsi bahwa penggelapan pajak etis dilakukan. Dengan demikian hipotesis yang diajukan:

$\mathrm{H}_{3}$ : Diskriminasi berpengaruh terhadap persepsi mengenai etika atas penggelapan pajak.

\section{Pengaruh Kualitas Pelayanan Pajak Terhadap Persepsi Mengenai Etika Atas Penggelapan Pajak.}

Dengan adanya kualitas pelayanan pajak yang baik, pengelolaan uang pajak dengan bijaksana, petugas pajak yang berkompeten dan tidak korupsi, serta prosedur pembayaran pajak yang tidak berbelitbelit, akan meningkatkan kepercayaan masyarakat terhadap fiskus dan mendorong kemauan membayar pajak, sehingga ketika wajib pajak merasa pelayanan yang diberikan kepadanya tidak sesuai dengan apa yang diharapkan, maka wajib pajak cenderung akan melakukan kecurangan yaitu penggelapan pajak, dan sebaliknya jika pelayanan yang diberikan oleh petugas pajak sudah baik dan dapat memenuhi harapan wajib pajak maka wajib pajak akan cenderung patuh membayar pajak.

Berdasarkan penelitian sebelumnya Tobing (2015) menunjukkan bahwa kualitas pelayanan pajak berpengaruh terhadap persepsi mengenai etika atas penggelapan pajak. Hal ini dikarnakan semakin tinggi kualitas pelayanan pajak maka prilaku penggelapan pajak dipandang sebagai prilaku yang tidak etis untuk dilakukan, sebaliknya semakin tidak baik kualitas pelayanan pajak maka prilaku penggelapan pajak dipandang sebagai prilaku yang cenderung etis untuk dilakukan. Dengan demikian hipotesis yang diajukan:

$\mathrm{H}_{4}$ : Kualitas Pelayanan Pajak berpengaruh terhadap persepsi mengenai etika atas penggelapan pajak.

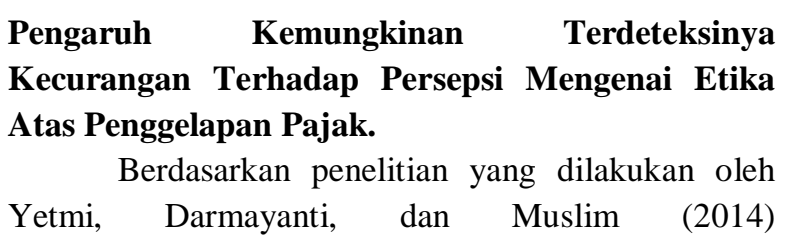


menyimpulkan bahwa kemungkinan terdeteksinya kecurangan tidak berpengaruh signifikan terhadap persepsi wajib pajak mengenai penggelapan pajak. Hal ini berbeda dengan penelitian yang dilakukan oleh Pulungan (2015) yang menyimpulkan bahwa kemungkinan terdeteksinya kecurangan berpengaruh terhadap penggelapan pajak, yang berarti semakin tinggi kemungkinan terdeteksinya kecuranngan, maka tingkat penggelapan pajak semakin rendah.

$\mathrm{H}_{5}$ : Kemungkinan terdeteksinya kecurangan berpengaruh terhadap persepsi mengenai etika atas penggelapan pajak.

Perbedaan persepsi mengenai etika atas penggelapan pajak pada dosen dengan mahasiswa universitas muhammadiyah surakarta.

Berdasarkan penelitian terdahulu di atas menunjukkan bahwa penentuan variabel sebagai Determinan Perspsi Mengenai Etika Atas Penggelapan Pajak yang nampak bebeda-beda. Hal tersebut yang mendasari untuk melakukan penelitian lebih lanjut mengenai Determinan Perspsi Mengenai Etika Atas Penggelapan Pajak pada dosen dan mahasiswa. Sehubung dengan hal tersebut dalam penelitian ini menggunakan variabel variabel Keadilan, Sistem Perpajakan, Diskriminasi, Kualitas Pelayanan Pajak dan Kemungkinan Terdeteksinya Kecurangan, maka dapat dibuat kerangka konseptual dan rangkaian hipotesisi sebagai berikut :

\section{Uji Beda}

Untuk menguji perbedaan persepsi mengenai etika atas penggelapan pajak pada dosen dengan mahasiswa di universitas muhammadiyah surakarta dikembangkan hipotesis keenam sebagai berikut :

H6 : Tidak ada perbedaan persepsi mengenai etika atas penggelapan pajak pada dosen dengan mahasiswa di universitas muhammadiyah surakarta.

\section{Metode Penelitian}

Penelitian ini merupakan penelitian empiris, untuk menguji faktor-faktor yang mempengaruhi persepsi mengenai etika atas penggelapan pajak pada dosen dan mahasiswa di universitas muhammadiyah surakarta. Desain penelitian ini adalah jenis penelitian kuantitatif, yaitu dengan menggunakan pertanyaan terstruktur yang sama pada setiap orang, kemudian semua jawaban yang diperoleh peneliti dicatat, diolah, dan dianalisis Sugiyono (2014) dalam Abrahams dan Kristanto (2016).

Populasi dalam penelitian ini adalah seluruh dosen tetap dan mahasiswa aktif Strata Satu (S1) Jurusan Akuntansi Fakultas Ekonomi dan Bisnis angkatan tahun 2013, 2014, dan 2015 di universitas muhammadiyah surakarta. Jumlah minimal sampel ditentukan dengan menggunakan rumus solvin. Berdasarkan data dari BPSDM total dosen tetap tercatat sebanyak 534 orang dan dan data dari kaprodi akuntansi total mahasiswa tercatat sebanyak 1260 orang di universitas muhammadiyah surakarta.

\section{Definisi Operasional dan Pengukuran Variabel}

\section{Keadilan (Variabel Independen)}

Menurut Banu (2008) dalam Elmiza, Fauziati dan Yunilma (2014) mengatakan keadilan pajak merupakan salah satu asas dalam aturan perpajakan, tetapi dalam hal pelaksanaan hal tersebut sering dianggap masyarakat tidak sesuai dengan maksud keadilan yang menjadi asas dari perpajakan. Variabel ini diukur dengan instrumen pengukuran dalam bentuk kuesioner dengan lima skala likert. Untuk setiap pemilihan responden atau jawaban diberi skor 1 untuk "Sangat Setuju (SS)," skor 2 untuk "Setuju (S)," skor 3 untuk "Netral (N)," skor 4 untuk "Tidak Setuju (TS)," dan skor 5 untuk "Sangat Tidak Setuju (STS)."

\section{Sistem Perpajakan (Variabel Independen)}

Menurut Resikno, Rini dan Novitasari (2014) sistem perpajakan adalah cara yang digunakan oleh pemerintah untuk memungut atau menarik pajak dari rakyat dalam rangka membiayai pembangunan dan pengeluaran pemerintah lainnya. Variabel ini diukur dengan instrumen pengukuran dalam bentuk kuesioner dengan lima skala likert. Untuk setiap pemilihan responden atau jawaban diberi skor 1 untuk "Sangat Setuju (SS)," skor 2 untuk "Setuju (S)," skor 3 untuk "Netral (N)," skor 4 untuk "Tidak Setuju (TS)," dan skor 5 untuk "Sangat Tidak Setuju (STS)."

\section{Diskriminasi (Variabel Independen)}

menurut Nickerson et al. (2009) dalam Ningsih dan Pusposari (2014) menjelaskan pemerintah dikatakan melakukan bentuk diskriminasi apabila 
kebijakan yang diterapkan hanya menguntungkan pihak tertentu saja, dan pihak lain dirugikan. Adanya diskriminasi yang dilakukan pemerintah akan mendorong sikap masyarakat untuk tidak setuju dengan kebijakan yang berlaku. Variabel ini diukur dengan instrumen pengukuran dalam bentuk kuesioner dengan lima skala likert. Untuk setiap pemilihan responden atau jawaban diberi skor 1 untuk "Sangat Setuju (SS)," skor 2 untuk "Setuju (S)," skor 3 untuk "Netral (N)," skor 4 untuk "Tidak Setuju (TS)," dan skor 5 untuk "Sangat Tidak Setuju (STS)."

\section{Kualitas Pelayanan Pajak(Variabel Independen)}

Menurut Murni, et al (2013) dalam Tobing, (2015) yaitu bentuk aktivitas atau kegiatan yang dilakukan oleh kantor pelayanan pajak terhadap pemenuhan kebutuhan wajib pajak dalam mengimbangi harapan wajib pajak. Kemauan wajib pajak untuk membayar pajak tergantung kualitas pelayanan petugas pajak. Variabel ini diukur dengan instrumen pengukuran dalam bentuk kuesioner dengan lima skala likert. Untuk setiap pemilihan responden atau jawaban diberi skor 1 untuk "Sangat Setuju (SS)," skor 2 untuk "Setuju (S)," skor 3 untuk "Netral (N)," skor 4 untuk "Tidak Setuju (TS)," dan skor 5 untuk "Sangat Tidak Setuju (STS)."

\section{Kemungkinan Terdeteksi Kecurangan}

Pemeriksaan adalah serangkaian kegiatan untuk mencari, mengumpulkan, mengolah data dan atau keterangan lainnya untuk menguji kepatuhan pemenuhan kewajiban perpajakan dan untuk tujuan lain dalam rangka melaksanakan ketentuan peraturan perundang-undangan perpajakan (Mardiasmo 2011:52). Variabel ini diukur dengan instrumen pengukuran dalam bentuk kuesioner dengan lima skala likert. Untuk setiap pemilihan responden atau jawaban diberi skor 1 untuk "Sangat Setuju (SS)," skor 2 untuk "Setuju (S)," skor 3 untuk "Netral (N)," skor 4 untuk "Tidak Setuju (TS)," dan skor 5 untuk "Sangat Tidak Setuju (STS)."

\section{Persepsi Mengenai Etika Atas Penggelapan Pajak (Variabel Dependen)}

Variabel kelima yaitu presepsi mengenai etika atas penggelapan pajak. McGee (2006) dalam Ningsih dan Pusposari (2014) pada penelitiannya menemukan penggelapan pajak tidak etis, namun ada beberapa mengatakan penggelapan pajak kadang-kadang dipandang etis atau bahkan selalu etis. Pandangan tersebut tentunya dilandasi oleh alasan-alasan dan fenomena yang ada di masyarakat.Variabel ini diukur dengan instrumen pengukuran dalam bentuk kuesioner dengan lima skala likert. Untuk setiap pemilihan responden atau jawaban diberi skor 1 untuk "Sangat Setuju (SS)," skor 2 untuk "Setuju (S)," skor 3 untuk "Netral (N)," skor 4 untuk "Tidak Setuju (TS)," dan skor 5 untuk "Sangat Tidak Setuju (STS)."

\section{Teknik Analisis Data}

Analisis dalam penelitian ini menggunakan persamaan regresi linier berganda. Analisis ini digunakan untuk mengetahui pengaruh lebih dari satu variabel independen terhadap variabel dependen.

\section{Hasil dan Pembahasan \\ Uji Kualitas Data}

Semua instrumen kuesioner yang meliputi variabel keadilan, sistem perpajakan, diskriminasi, kualitas pelayanan pajak, kemungkinan terdeteksinya kecurangan, dan persepsi mengenai etika atas penggelapan pajak mempunyai $r_{\text {hitung }}>r_{\text {tabel }}$, maka semua item pertanyaan tersebut dapat dinyatakan valid mengukur suatu variabel. Hasil analisis reliabilitas diketahui bahwa seluruh item pertanyaan dari masingmasing variabel dalam penelitian ini adalaah reliabel. Hal ini ditunjukkan oleh nilai cronbach alpha dari masing-masing variabel bernilai lebih dari 0,60

\section{Pengujian Asumsi Klasik}

Hasil uji Kolmogorov-Smirnov $Z$ pada dosen menunjukkan sebesar 0,473 dan pada mahasiswa menunjukkan sebesar 0,189 , maka dapat disimpulkan bahwa data berdistribusi normal, karena $\mathrm{p}$ (sig.) > 0,05 . Hasil uji multikolineritas menunjukkan bahwa seluruh variabel independen memiliki nilai VIF kurang dari 10 dan nilai tolerance $>0,1$, sehingga dapat disimpulkan bahwa model tidak terjadi multikolinearitas. Kemudian hasil uji heteroskedastisitas menunjukkan bahwa semua variabel bebas menunjukkan nilai sig lebih besar dari 0,05 , sehingga dapat disimpulkan bahwa semua variabel bebas dari heteroskedastisitas.

\section{Pengujian Hipotesis}




\section{Analisis Regresi Linier Berganda}

Hasil analisis regresi linier berganda dapat dilihat pada tabel 1 dan tabel 2 .

Tabel 1.

Hasil Analisis Regresi pada Dosen

\begin{tabular}{|l|c|c|c|}
\hline \multirow{1}{*}{ Variabel } & $\begin{array}{c}\text { Unstan } \\
\text { dardized } \\
\text { Coefficients }\end{array}$ & $\mathrm{t}$ & Sig. \\
\cline { 2 - 4 } & $\mathrm{B}$ & & \\
\hline (Constant) & 36,536 & 8,437 & 0,000 \\
Keadilan & $-0,132$ & $-0,926$ & 0,357 \\
$\begin{array}{l}\text { Sistem } \\
\text { Perpajakan }\end{array}$ & $-0,849$ & $-9,163$ & 0,000 \\
$\begin{array}{l}\text { Diskriminasi } \\
\text { Kualitas }\end{array}$ & 0,326 & 2,261 & 0,027 \\
$\begin{array}{l}\text { Pelayanan } \\
\text { Pajak }\end{array}$ & $-0,319$ & $-2,272$ & 0,026 \\
$\begin{array}{l}\text { Kemungkinan } \\
\text { Terdeteksinya }\end{array}$ & $-0,269$ & $-1,579$ & 0,118 \\
Kecurangan & & & \\
\hline
\end{tabular}

Tabel 2.

Hasil Analisis Regresi pada Mahasiswa

\begin{tabular}{|l|c|c|c|}
\hline \multirow{1}{*}{ Variabel } & $\begin{array}{c}\text { Unstan } \\
\text { dardized } \\
\text { Coefficients }\end{array}$ & $\mathrm{t}$ & Sig. \\
\cline { 2 - 4 } & $\mathrm{B}$ & & \\
\hline (Constant) & 8,641 & 2,813 & 0,006 \\
Keadilan & 0,218 & 1,563 & 0,121 \\
Sistem & 0,212 & 1,809 & 0,074 \\
Perpajakan & 0,527 & 3,736 & 0,000 \\
$\begin{array}{l}\text { Diskriminasi } \\
\text { Kualitas }\end{array}$ & $-0,345$ & $-2,539$ & 0,013 \\
Pelayanan & & & \\
Pajak & & 1,679 & 0,096 \\
Kemungkinan & 0,297 & & \\
Terdeteksinya & & \\
Kecurangan & &
\end{tabular}

Hasil analisis regresi linier berganda untuk Dosen adalah sebagai berikut:

$\mathrm{PEPP}=36,536-0,132 \mathrm{KD}-0,849 \mathrm{SP}+0,326 \mathrm{DS}-$ $0,319 \mathrm{KPP}-0,269 \mathrm{KTK}+\varepsilon$
Sedangkan Regresi untuk Mahasiswa adalah sebagai berikut:

$\mathrm{PEPP}=8,614+0,218 \mathrm{KD}+0,212 \mathrm{SP}+0,527 \mathrm{DS}-$ $0,345 \mathrm{KPP}+0,297 \mathrm{KTK}+\varepsilon$

Berdasarkan persamaan regresi linier diatas dapat diinterpretasikan bahwa nilai koefisien regresi masing-masing mempunyai nilai positif dan negatif. Jika bernilai positif dapat diartikan bahwa apabila semakin tinggi keadilan, Sistem Perpajakan, Diskriminasi, Kualitas Pelayanan Pajak dan Kemungkinan Terdeteksi Kecurangan maka Dosen dan Mahasiswa masih ada yang menganggap penggelapan pajak etis untuk dilakukan. Kemudian jika bernilai negatif dapat diartikan bahwa apabila semakin tinggi keadilann, Sistem Perpajakan, Diskriminasi, Kualitas Pelayanan Pajak dan Kemungkinan Terdeteksi Kecurangan maka Dosen dan Mahasiswa menganggap bahwa penggelapan pajak tidak etis untuk dilakukan.

\section{Uji t}

Berdasarkan hasil analisis uji $t$ dapat diketahui bahwa Pada variabel Keadilan menunjukkan nilai sig sebesar 0,357 untuk Dosen dan 0,121 untuk Mahasiswa, nilai signifikan keduanya lebih besar dari 0,05 dan $t_{\text {hitung }}<t_{\text {tabel }}$ (1,991 untuk dosen dan 1,986 untuk mahasiswa) maka $\mathrm{H}_{1}$ ditolak. Pada variabel Sistem Perpajakan menunjukkan nilai sig sebesar 0,000 untuk dosen dan 0,074 mahasiswa, nilai signifikan untuk dosen lebih kecil dari 0,05 dan $\mathrm{t}_{\text {hitung }}$ $>t_{\text {tabel }}(1,991)$ maka $\mathrm{H}_{2}$ untuk persepsi dosen diterima, sedangkan Nilai signifikan untuk mahasiswa lebih besar dari 0,05 dan $\mathrm{t}_{\text {hitung }}<\mathrm{t}_{\text {tabel }}(1,986)$ maka $\mathrm{H}_{2}$ untuk persepsi mahasiswa ditolak. Pada variabel Diskriminasi menunjukkan nilai sig sebesar 0,027 untuk dosen, dan 0,000 untuk mahasiswa, nilai signifikan keduanya lebih kecil dari 0,05 dan $\mathrm{t}_{\text {hitung }}>$ $t_{\text {tabel }}(1,991$ untuk dosen dan 1,986 untuk mahasiswa) maka $\mathrm{H}_{3}$ diterima.

Pada variabel Kualitas Pelayanan Pajak menunjukkan nilai sig sebesar 0,026 untuk dosen dan 0,013 untuk mahasiswa, nilai signifikan keduanya lebih kecil dari 0,05 dan $t_{\text {hitung }}>t_{\text {tabel }}(1,991$ untuk dosen dan 1,986 untuk mahasiswa) maka $\mathrm{H}_{4}$ diterima. Pada variabel Kemungkinan Terdeteksinya Kecurangan menunjukkan nilai sig sebesar 0,118 
untuk Dosen dan 0,096 untuk Mahasiswa, nilai signifikan keduanya lebih besar dari 0,05 dan $t_{\text {hitung }}<$ $\mathrm{t}_{\text {tabel }}(1,991$ untuk dosen dan 1,986 untuk mahasiswa) maka $\mathrm{H}_{5}$ ditolak.

\section{Uji F}

Hasil uji $\mathrm{F}$ diperoleh nilai $\mathrm{F}_{\text {hitung }}$ pada Dosen sebesar 26,982 lebih besar dari $\mathrm{F}_{\text {tabel }} 2,33$ dan sig < 0,05 yaitu $0,000<\alpha=0,05$. Sedangkan pada Mahasiswa sebesar 13,497 lebih besar dari $F_{\text {tabel }} 2,31$ dan sig $<0,05$ yaitu $0,000<\alpha=0,05$. Maka dapat disimpulkan bahwa secara keseluruhan variabelvariabel independen yang meliputi keadilan, sistem perpajakan, diskriminasi, kualitas pelayanan pajak, dan kemungkinan terdeteksinya kecurangan mempunyai pengaruh secara bersama-sama terhadap persepsi mengenai etika atas penggelapan pajak.

\section{Uji Koefisien Determinasi $\left(\mathbf{R}^{2}\right)$}

Hasil analisis diketahui untuk nilai adjusted $\mathrm{R}^{2}$, dalam analisis regresi linier berganda, untuk dosen angka koefisien determinasi atau adjusted $\mathrm{R}^{2}$ sebesar 0,610 . Hal ini berarti bahwa $61 \%$ variabel persepsi mengenai etika atas penggelapan pajak dapat dijelaskan oleh variabel keadilan, sistem perpajakan, diskriminasi, kualitas pelayanan pajak, dan kemungkinan terdeteksinya kecurangan, sedangkan sisanya yaitu $39 \%$ dijelaskan oleh variabel-variabel lain di luar penelitian ini. Sedangkan untuk mahasiswa angka koefisien determinasi atau adjusted $\mathrm{R}^{2}$ sebesar 0,387. Hal ini berarti bahwa 38,7 \% variabel persepsi mengenai etika atas penggelapan pajak dapat dijelaskan oleh variabel keadilan, sistem perpajakan, diskriminasi, kualitas pelayanan pajak, dan kemungkinan terdeteksinya kecurangan, sedangkan sisanya yaitu $61,3 \%$ dijelaskan oleh variabel-variabel lain di luar penelitian ini.

\section{Pembahasan}

\section{Pengaruh keadilan terhadap persepsi mengenai etika atas penggelapan pajak}

Hasil penelitian menunjukkan hasil negatif dan tidak berpengaruh untuk Dosen. Jadi, penggunaan uang yang bersumber dari pajak adil atau tidak adil tidak akan berpengaruh terhadap persepsi dosen mengenai etika penggelapan pajak karena pajak sudah menjadi kewajiban seluruh warga negara yang wajib dibayarkan dan penggelapan pajak merupakan tindakan yang tidak etis. Sedangkan hasil penelitian menunjukkan hasil positif dan tidak berpengaruh untuk Mahasiswa. Dengan adanya berbagai tindak kecurangan yang terjadi di pemerintahan, tentu dapat mendorong mahasiswa untuk cenderung berpikir lebih baik tidak membayar pajak daripada uang tersebut akan habis dikorupsi oleh pemerintah. Hal ini menunjukkan bahwa penggunaan uang yang bersumber dari pajak secara adil ataupun tidak adil, tidak akan berpengaruh terhadap persepsi masyarakat khususnya mahasiswa mengenai etika atas penggelapan pajak karena kepercayaan mahasiswa terhadap pemerintah mulai berkurang dan cenderung berpendapat penggelapan pajak selalu etis dilakukan.

Hasil dari analisis penelitian ini sesuai dengan penelitian yang dilakukan oleh Ningsih dan Pusposari (2014) dan Suminarisasi dan Supriyadi (2011) yang mengemukakan adil atau tidaknya suatu keadilan tidak berpengaruh terhadap persepsi mengenai etika atas penggelapan pajak.

\section{Pengaruh sistem perpajakan terhadap persepsi mengenai etika atas penggelapan pajak}

Hasil penelitian menunjukkan hasil negatif untuk Dosen. Dengan adanya sistem perpajakan yang baik pengelolaan uang pajak yang dapat dipertanggungjawabkan, petugas pajak yang kompeten dan tidak korupsi, dan juga prosedur perpajakan yang tidak berbelit-belit akan membuat wajib pajak enggan untuk menggelapkan pajak. Sehingga penggelapan pajak dianggap sebagai perilaku yang tidak etis. Sedangkan hasil penelitian menunjukkan hasil positif dan tidak berpengaruh untuk Mahasiswa. Dengan adanya pengelolaan uang pajak tidak jelas, ditambah lagi petugas pajaknya justru melakukan tindakan korupsi uang pajak, maka Wajib Pajak enggan untuk melaporkan kewajibannya dengan jujur, mereka akan cenderung untuk menggelapkan pajak, karena dia merasa bahwa sistem pajak yang ada belum cukup baik mengakomodir segala kepentingan. Sehingga sistem perpajakan tidak dapat mempengaruhi persepsi mahasiswa terhadap etika penggelapan pajak.

Hasil dari analisis penelitian dosen ini sesuai dengan penelitian yang dilakukan oleh Ningsih dan Pusposari (2014) Suminarisasi dan Supriyadi 
(2011) dan Silaen (2014) yang mengemukakan bahwa semakin baik sistem perpajakannya maka perilaku penggelapan pajak dianggap sebagai perilaku yang tidak etis dilakukan. Sedangkan hasil dari penelitian mahasiswa sesuai dengan penelitian yang dilakukan oleh Elmiza, Fauziati, dan Yunilma (2014) yang menyatakan sistem perpajakan tidak berpengaruh terhadap etika penggelapan pajak.

\section{Pengaruh diskriminasi terhadap persepsi mengenai etika atas penggelapan pajak}

Hasil penelitian ini menunjukkan hasi positif bagi persepsi mengenai etika atas penggelapan pajak. Yang menyatakan bahwa semakin banyak bentuk diskriminasi dalam peraturan perpajakan yang berlaku, maka penggelapan pajak merupakan persepsi yang etis dan sebaliknya semakin rendah tingkat diskriminasi maka penggelapan pajak merupakan persepsi yang tidak etis.

Hasil dari analisis penelitian ini sesuai dengan penelitian yang dilakukan oleh Ningsih dan Pusposari (2014) Suminarisasi dan Supriyadi (2011) Elmiza, Fauziati dan Yunilma(2014) dan Silaen (2015) yang mengemukakan diskriminasi berpengaruh terhadap persepsi mengenai etika atas penggelapan pajak.

\section{Pengaruh kualitas pelayanan pajak terhadap persepsi mengenai etika atas penggelapan pajak}

Hasil penelitian ini menunjukkan hasi negatif bagi persepsi mengenai etika atas penggelapan pajak. Ketika pelayanan yang diberikan oleh petugas pajak sudah baik dan dapat memenuhi harapan wajib pajak maka wajib pajak akan cenderung patuh membayar pajak, dan memandang penggelapan pajak sebagai tindakan ilegal, tidak etis dan melanggar hukum. Sebaliknya jika wajib pajak merasa pelayanan yang diberikan kepadanya tidak sesuai dengan apa yang diharapkan, sehingga wajib pajak memandang penggelapan pajak sebagai tindakan yang legal, etis dan tidak melanggar hukum maka wajib pajak cenderung akan melakukan kecurangan yaitu penggelapan pajak.

Hasil dari analisis penelitian ini sesuai dengan penelitian yang dilakukan oleh Tobing (2015) dan Rachmadi dan Zulaikha (2014) yang mengemukakan kualitas pelayanan pajak berpengaruh terhadap persepsi mengenai etika atas penggelapan pajak.

\section{Pengaruh kemungkinan terdeteksinya kecurangan terhadap persepsi mengenai etika atas penggelapan pajak}

Hasil penelitian ini menunjukkan hasi negatif dan tidak berpengaruh untuk Dosen. Ada atau tidaknya kemungkinan terdeteksi kecurangan tidak mempengaruhi persepsi mengenai etika atas penggelapan pajak, karena dosen tetap memiliki persepsi bahwa penggelapan pajak tidak etis untuk dilakukan. Sedangkan hasil penelitian menunjukkan hasil positif dan tidak berpengaruh untuk Mahasiswa. Ada atau tidaknya kemungkinan terdeteksinya kecurangan mempengaruhi persepsi mengenai etika atas penggelapan pajak, karena mahasiswa memiliki persepsi bahwa penggelapan pajak tetap etis untuk dilakukan. Pemeriksaan yang dilakukan oleh pihak fiskus akan dapat memberikan peluang bagi wajib pajak untuk bekerja sama dengan petugas, karena adanya petugas yang mudah untuk disuap dengan cara melakukan kompromi dan bekerja sama antara petugas pajak dengan wajib pajak dengan imbalan tertentu. Sehingga kecurangan yang dilakukan oleh wajib pajak akan sulit terdeteksi oleh pihak fiskus.

Hasil dari analisis penelitian ini sesuai dengan penelitian yang dilakukan oleh Yetmi, Darmayanti, dan Muslim (2014), hasil penelitian menyatakan bahwa kemungkinan terdeteksinya kecurangan tidak berpengaruh terhadap persepsi penggelapan pajak.

\section{Simpulan}

Berdasarkan data yang telah dikumpulkan dan pengujian dengan analisis regresi berganda yang telah dilakukan untuk menguji hipotesis, maka kesimpulan dari penelitian ini adalah menurut dosen dan mahasiswa $\mathrm{H}_{1}$ ditolak artinya keadilan tidak berpengaruh terhadap persepsi mengenai etika atas penggelapan pajak. Sistem Perpajakan menurut dosen berpengaruh sedangkan mahasiswa tidak berpengaruh terhadap persepsi mengenai etika atas penggelapan pajak, oleh karena itu menurut Dosen $\mathrm{H}_{2}$ diterima dan menurut Mahasiswa $\mathrm{H}_{2}$ ditolak. Diskriminasi menurut dosen dan mahasiswa berpengaruh terhadap persepsi mengenai etika atas penggelapan pajak, oleh karena itu $\mathrm{H}_{3}$ diterima. Kualitas Pelayanan Pajak menurut dosen dan mahasiswa berpengaruh terhadap persepsi mengenai etika atas penggelapan pajak, oleh karena itu 
$\mathrm{H}_{4}$ diterima. Kemungkinan Terdeteksinya Kecurangan menurut dosen dan mahasiswa tidak berpengaruh terhadap persepsi mengenai etika atas penggelapan pajak, oleh karena itu $\mathrm{H}_{5}$ ditolak.

Kemudian setelah dilakukan uji beda, maka hasilnya tidak ada perbedaan secara statistik persepsi mengenai etika atas penggelapan pajak antara Dosen dengan Mahasiswa di Universitas Muhammadiyah Surakarta

\section{Referensi}

[1] Abrahams dan Kristanto.2016. "Persepsi Calon Wajib Pajak Dan Wajib Pajak Terhadap Etika Penggelapan Pajak Di Salatiga". Berkala Akuntansi dan Keuangan Indonesia Vol 1 No 1.Universitas Kristen Satya Wacana.

[2] Elmiza, Fauziati dan Yunilma. 2014. "Pengaruh Keadilan, Sistem Perpajakan, dan Diskriminasi terhadap Persepsi Wajib Pajak Mengenai Etika Penggelapan Pajak (Tax Evasion)".ejurnal bunghatta vol 4 No 1. Universitas Bung Hatta.

[3] Febriana.2015. "Kualitas Pelayanan Pajak Di Kantor Pelayanan Pajak Pratama Bojonegoro".ejournal UNESA Vol 3 No8. Universitas Negeri Surabaya.

[4] Fickar. (2014). Catatan Hukum tentang Penuntasan Eksekusi Kasus Pajak Asian Agri. Diakses melalui http://www.kompasiana.com/fickar15/ catatanhukum-tentang-penuntasan-eksekusikasus-pajak-asian-agri Pada 15 oktober 2016

[5] Friskianti dan Handayani. 2014. Pengaruh Self Assessment System, Keadilan, Teknologi Perpajakan, Dan Ketidakpercayaan Kepada Pihak Fiskus Terhadap Tindakan Tax Evasion. Accounting analysis journal. Universitas negeri Semarang. Semarang.

[6] Ghozali, Imam. 2011. "Aplikasi Analisis Multivariate Dengan Program IBM SPSS 19, Edisi 5". Badan Penerbit Universitas Diponegoro. Semarang.

[7] Handayani dan Cahyonowati (2014). Analisis Faktor-Faktor Yang Mempengaruhi Persespsi Wajib Pajak Mengenai Penggelapan Pajak. Semarang: Jurusan Akuntansi Fakultas Ekonomi dan Bisnis Universitas Diponegoro. Diponegoro Journal of Accounting, Volume 3, Nomor 3, tahun 2014, Hal 1-7.
[8] Handayani Wahyu (2013), “Atribusi” diakses melalui http://blogwahyu statistika.blogspot.com/2013/02/pengertianatribusi-psikologi.html pada 29 oktober 2016

[9] Indrianto dan Supomo, "Metode Penelitian Bisnis", Edisi Pertama, Penerbit BPFE, Yogyakarta, 2014

[10] Indriyani, Nurlaela dan Wahyuningsih.2016. "Pengaruh Keadilan, Sistem Perpajakan, Diskriminasi, Dan Kemungkinan Terdeteksinya Kecurangan Terhadap Persepsi Wajib Pajak Orang Pribadi Mengenai Perilaku Tax Evasion. ”. ISSN:2337-4349.

[11] Kemenpen No 63 Tahun 2003 tentang Pedoman Umum Penyelenggaraan Pelayanan Publik.

[12] Kurniawati dan Toly. 2014. "Analisis Keadilan Pajak, Biaya Kepatuhan, dan Tarif Pajak Terhadap Persepsi Wajib Pajak Mengenai Penggelapan Pajak Di Surabaya Barat". Tax \& Accounting Review Vol 4 No 2. Universitas Kristen Petra.

[13]Linda, Tarjo, dan Muhammad. 2013. "Pengaruh Keadilan, Kualitas Pelayanan Pajak, dan Kemungkinan Terdeteksinya kecurangan Terhadap Persepsi Wajib pajak Mengenai Tax Evasion". Seri Kajian Ilmiah. Universitas Trunojoyo madura.

[14] Mardiasmo. 2011. "Perpajakan Edisi Revisi 2011". Yogyakarta: Penerbit Andi.

[15] McGee et,al (2008). A Comparative Study on Perceived Ethics of Tax Evasion: Hong Kong Vs the United States.Hong Kong Baptist University and Barry University. Journal of Business Ethics.(2008) 77:147-158

[16] McGee, $\quad$ R.W., $\quad$ Nickerson,I., Pleshko.L.P.,Broihahn,M. 2012. "The Ethics Of Tax Evasion: An Investigation Into Demographic Differences". Journal of Legal, Ethical and Regulatory Issues, Volume 15, Number 1.

[17] Mujiyati dan M.Abdul Aris.2014.Perpajakan Kontemporer. Surakarta: Muhammadiyah University Press (MUP).

[18] Mukharoroh. 2014. "Analisis Faktor-Faktor Yang Mempengaruhi Persepsi Wajib Pajak Mengenai Penggelapan Pajak (Studi Empiris pada Wajib 
Pajak Pribadi di Kota Semarang)”. Skripsi. Semarang: Universitas Diponegoro.

[19] Nasikhudinisme . (2015), "Tax Evasion dan Tax Avoidance", diakses melalui https://nasikhudinisme.com/tag/tax-evasion-dantax-avoidance/ pada tanggal 3 Oktober 2016

[20] Ningsih dan Pusposari. 2015. "Determinan Persepsi Mengenai Etika Atas Penggelapan Pajak (Tax Evasion) (Studi Kasus pada Mahasiswa Jurusan Akuntansi Fakultas Ekonomi dan Bisnis Universitas Brawijaya)". Jurnal. Universitas Brawijaya. Malang.

[21] Peraturan Pemerintah Nomor 60 Tahun 2010 tentang zakat atau sumbangan keagamaan

[22] Prasetyo, Sigit. 2010. "Persepsi Etis Penggelapan Pajak Bagi Wajib Pajak Di Wilayah Surakarta". Skripsi. Fakultas Ekonomi Universitas Sebelas Maret. Surakarta.

[23] Pulungan.2015. "Pengaruh Keadilan, Sistem Perpajakan, Dan Kemungkinan Terdeteksinya Kecurangan Terhadap Persepsi Wajib Pajak Mengenai Etika Penggelapan Pajak (Tax Evasion)”. JOM FEKON Vol 2 No 1. Universitas Riau.

[24] Puspareni (2012), “Atribusi" diakses melalui http://puspareni.blogspot.com /2012/05/atribusi.html pada 1 November 2016

[25] Rachmadi dan Zulaikha. 2014. Faktor-Faktor Yang Mempengaruhi Persepsi Wajib Pajak Orang Pribadi Atas Perilaku Penggelapan Pajak (studi empiris pada wajib pajak terdafatar di KPP pratama semarang candisari). Diponegoro Journal Of Accounting. Semarang:Universitas Diponegoro.

[26] Rahman,I. S. 2013. "Pengaruh Keadilan, Sistem Perpajakan, Diskriminasi, dan Kemungkinan Terdeteksinya Kecurangan Terhadap Persepsi Wajib Pajak Mengenai Etika Penggelapan Pajak (Tax Evasion)". Skripsi. Jakarta: Jurusan Akuntansi Fakultas Ekonomi dan Bisnis Universitas Islam Negeri Syarif Hidayatullah.

[27]Reskino, Rini dan Novitasari (2014). Persepsi Mahasiswa Akuntansi Mengenai Penggelapan Pajak. Jakarta: Fakultas Ekonomi dan Bisnis UIN Syarif Hidayatullah. Jurnal InFestasi, Volume 10 No. 1, Hal. 49-63
[28] Silaen.2015. "Pengaruh Sistem Perpajakan, Diskriminasi, Teknologi Dan Informasi Perpajakan Terhadap Persepsi Wajib Pajak Mengenai Etika Penggelapan Pajak (Tax Evasion)". JOM FEKON Vol 2 No 2. Universitas Riau.

[29] Sugiyono, "Metode Penelitian Bisnis", Penerbit Alfabeta, Bandung, 2009

[30] Sultoni. (2013). PMK 16/PMK.03/2013 Makin Meneguhkan DJP. Diakses melalui http://www.pajak,go.id/content/article/pmk16pmk032013makin-meneguhkan-djp pada 10 Oktober 2016

[31] Suminarsasi dan Supriyadi.2011."Pengaruh Keadilan,Sistem Perpajakan dan Diskriminasi terhadap Persepsi Wajib Pajak mengenai Etika Penggelapan Pajak (Tax Evasion)".Jurnal Simposium Nasional Akuntansi XV. Universitas Gajah Mada.Yogyakarta.

[32] Tobing.2015. "Pengaruh Keadilan Pajak, Kualitas Pelayanan Pajak, Kemungkinan Terdeteksinya Kecurangan, Sanksi Perpajakan,Dan Tarif Pajak Terhadap Persepsi Wajib Pajak Mengenai Penggelapan Pajak". jom FEKON Vol 2 No 2.

[33] Trihastutie. 2009. Penghindaran atau penggelapan pajak? http://trihastutie.wordpress.com diakses pada 01 Oktober 2016 pukul 07.35

[34] Ulfa (2015). Pengaruh Kemungkinan Terdeteksinya Kecurangan, Teknologi dan Informasi Perpajakan, dan Kepercayaan Pada Otoritas Pemerintah Terhadap Penggelapan Pajak (Studi Empiris pada Orang Pribadi Yang Terdaftar di Kantor Pelayanan Pajak Pratama Senapelan Pekanbaru). Pekanbaru: Fakultas Ekonomi Universitas Riau.Volume 2 Nomor 2.

[35] Undang-Undang Nomor 28 Tahun 2007 mengenai Ketentuan Umum Perpajakan.

[36] Undang-Undang Republik Indonesia Nomor 16 Tahun 2009 Tentang Ketentuan Umum dan Tata Cara Perpajakan.

[37] Undang-Undang Republik Indonesia Nomor 39 Tahun 1999 tentang Hak Asasi Manusia.

[38] Waluyo. 1999. "Perpajakan Indonesia". Jakarta: Penerbit Salemba Empat 
[39] Wicaksono, Kunto Adi. 2014. Etika Penggelapan Pajak (Tax Evasion): Perbedaan Persepsi Mahasiswa Ekonomi, Hukum dan Psikologi. Gajah Mada Journal of Accounting. Universitas Gajah Mada.

[40] Yetmi, Darmayanti dan Muslim.2014. "Faktorfaktor Yang Mempengaruhi Persepsi Wajib Pajak Mengenai Penggelapan Pajak". Jurnal Universitas Bung Hatta Volume 1 Nomor 5. Universitas Bung Hatta. 